\title{
Reinforcement Engineering Professional Characteristics in the Process of Professional Accreditation
}

\author{
Shang Zhendong, Cai Haichao, Cheng Yonghui, Xu Qiaoyu \\ School of Mechatronics Engineering \\ Henan University of Science \&Technology \\ Luoyang, Henan Province, 471003, China \\ cnzzszd@163.com
}

\begin{abstract}
The present study was to solve the problem of how to cultivate and develop specialized characteristics in the process of engineering education professional accreditation. The relationship between the two points above has been analyzed. The results show that it is easier for the characteristic specialty to pass the accreditation on engineering education, the forming and development of the specialized characteristics depends on the professional accreditation. This article gives suggests as follows: engineering educators should possess the correct attitude on authentication, know deeply about the certification standards, regulate the behavior of certification, and combined with their own characteristics. For the engineering majors, its guide of educational goal is to cultivate talents meeting industry's demand, stand on the concept of taking students as the center and keeping continuous improvement, combine co-operation of industries and schools with the modern information technology, reform precisely on the talents supply, improve the sense of learning of students. Therefore, it can be realized that the normative accreditation can be used to focus and strengthen the characteristic, to promote the quality of personnel training, to develop the engineering majors in characteristic way.
\end{abstract}

Keywords-Engineering education, professional accreditation, Speciality Characteristics, Engineering Discipline

\section{INTRODUCTION}

Engineering education professional certification not only can make the engineering education adapt to economic globalization on the internationalization of engineering talent requirements, and can ensure the quality of engineering education. Therefore, the engineering education accreditation has become the focus of the current colleges and universities, and other social from all social circles. Until 2013 Chinese engineering education accreditation association of colleges and universities has finished the certification work for 373 professional. [1]

Refers to fully embody the characteristics of professional school orientation, the education goal, teaching staff, curriculum system, teaching condition and training quality, etc., have higher education levels and distinctive characteristics, social identity and have higher social reputation of professional [2]. Characteristic specialties generally have strong influence at home and abroad, fit with the social demand and have the advantages of disciplines to support [3]. Characteristic professional is not achieved overnight, nor self-appointed. It is gradually formed in the long history of running colleges and universities, and be able to keep pace with the times, long-term advantages to keep running. It is recognized in interacting with society, a specialty in a university can be accepted as Characteristic professional only when the target of talent training fits social needs well, the graduates can make great contribution to the development and progress of society, the professional features can be widely recognized by the society.

The purpose of this paper is to discuss the relationship between engineering education accreditation and the characteristics of engineering specialty construction, provide reference for formation and strengthening of engineering education accreditation the professional characteristic under the background.

\section{ENGINEERING EDUCATION ACCREDITATION AND THE CHARACTERISTICS PROFESSIONAL CONSTRUCTION}

\section{A. Engineering Education Certification Promotes Engineering Characteristics}

Characteristics of professional teachers in service industry are able to provide a targeted guidance in the society development and solve the problem of the specific engineering practice. More importantly, the characteristic graduates can adapt to industry needs, and have made outstanding contributions to the industry, get social recognition. Therefore, an engineering specialty wants to have the characteristics, first of all its personnel training target must fit with industry personnel demand. The aims and objectives of the engineering education accreditation are to improve engineering education to cultivate professional talents in accordance with the actual demand in the field of engineering. This is mainly embodied in the establishment of professional certification association with industry representatives, and formulation of certification standards system are absorbed the opinions and suggestions of the industry, such as the industry professionals to participate in certification process. Therefore, certification can improve engineering education goals and the degree of match among industry talent demand, is advantageous to the professional formation characteristics. 
Engineering education accreditation have great social influence, through the certification itself means that engineering education quality in colleges and universities has reached the industry standard, equivalent to the professional and quality certificate issued by the education teaching certificate. Both determine its position in the industry and won the school recruitment of students, students' employment and professional future development opportunities, are conducive to form professional predominance.

\section{B. Engineering Education Accreditation Consolidate Characteristics}

Engineering education accreditation is to facilitate a process of improving the teaching quality for the engineering specialty, and continuous improvement is one of the basic ideas Engineering education accreditation system regulation: certified professional to maintain certification valid continuous, must be resubmitted in the first half of a year prior to the expiration of the valid period of certification [4]. Engineering education accreditation emphasizes on certification, strict standards accreditation also emphasizes on teachers, students and professional use of evaluation results for loop has improved, has risen in a spiral of teaching quality and improvement, it for promoting professional better adapt to social change and technological innovation has played a key role.

With the rapid development of society, economy, science and technology, an industry demand for talent development will also change. Talents training goal of the higher engineering education should also change with industry demand, and constantly adjust to keep consistent with industry demand, featuring professional consolidate establish long-term effective mechanism of quality assurance.

\section{Provide Certified Support for Professional Characteristics}

Characteristics of professional performance for advanced education idea, training mode efficient, strong faculty and professional condition is superior, the training target, course system, must also conform to the industry's needs. Comparison of engineering education accreditation standards found these aspects is the certification requirements. Characteristic if is recognized as a major, the accumulation of talent cultivation model must accord with the requirement of professional certification, intentionally or unintentionally. So, professional characteristics will make a professional certified.

Engineering education accreditation to main object in the certification of the students' learning outcomes, engineering education accreditation standards set by the professional graduation requirements should be completely covered engineering knowledge, problem analysis and solution design/development, research, engineering, using modern tools and society, environment and sustainable development, professional norms, individual and team, communication, project management and lifelong development, a total of 12 specific content [4]. Certification standards also make requirements for teachers: teachers have enough teaching ability, engineering experience, professional level, communication ability, career development, and the ability to carry out studies of engineering practice, to participate in academic exchanges [4]. Characteristics are more likely to attract outstanding professional teachers and students with high quality, coupled with advanced education idea and education mode is excellent, as a result, more easily than other professional feature specialty meet certification standards.

Features due to the professional can simultaneously by education of peers and industry acclaim, and engineering education accreditation panel is composed of the education field and profession technical personnel, so features were more vulnerable to professional certified professional recognition.

\section{Not Standardized Behavior of the Certification of Damaging to Professional Characteristics}

Engineering education accreditation can effectively promote the formation and the strengthening of the professional characteristics, however, not standardized authentication behavior also can damage the professional characteristic. Because of their utility and impetuous and unreasonable guide environment, our country's higher education appeared in the great achievements as well as convergence, does not favor the characteristic specialty construction.

Engineering education accreditation for the professional teaching should meet the basic standards, have played an important role in the baton for engineering specialty teaching, and belongs to a kind of social norm mechanism. Social norm mechanism is through some training to members of the organization with a common mind and common ideas, the common concept to guide the people and organization development along the same or similar paths [5]. Engineering education accreditation engineering specialty of universities has the training of the concept of the common mind and common features, many colleges and universities to take an active part in and widespread attention from all walks of life constantly strengthen its binding force, and guide the professional certification along the path of the same or similar development, therefore, engineering education accreditation is to guide the development path of convergence.

\section{TO STRENGTHEN THE PROFESSIONAL CHARACTERISTIC IN THE ENGINEERING EDUCATION ACCREDITATION}

Characteristic specialized construction involves all aspects of the teaching reform, should not only conform to the requirements of the country's development, and should follow the objective laws of education, and combined with the characteristics and orientation in education school.

\section{A. The Certification Attitude, Concept of Certification}

Should apply for certification of college professional certification attitude, engineering education accreditation as an opportunity to improve the quality of their own talent training, certification, promoting development, formed in the process of certification and strengthen characteristic, and can not muddle through, trying to muddle through. Should be controlled in the process of certification standards, and actively look for, serious rectification, not blindly copy, forgery. Also only in this way can not only ensure good results of engineering education 
accreditation, and avoid mill certification process to their edges and damage to specialty. For other colleges and universities in the engineering education accreditation certification approach to specific issues specific analysis, to the actual situation of the thorough analysis in combination with other universities and why, and in the process of certification from the concept, principle, using for reference.

In the background of higher engineering certification, colleges and universities should stick to the concept of certification. "student-centered "," goal orientation "and" continuous improvement " are the basic concepts of engineering education accreditation. These reflect the current international engineering education development trend of advanced concept has a good effect on the construction of engineering specialty.

\section{B. Dig Through Certification Standards, to Establish the Mapping Relationship with Teaching}

For engineering education accreditation work in 2016, officials said, according to the requirements of the international substantial equivalence, the core values of dig through certification and quality standard [6]. Engineering in engineering education professional certification standards, should be further investigated in the process of accurate understanding and faithfully implement in the process of certification standards. Only in this way can pass certification and strengthen their own professional characteristics.

The engineering education accreditation standard requires that engineering majors should be trained to measure in graduates, in the form of knowledge, quality and ability requirements. The certification program shall have the training goal of public, conforming to the school orientation and meet the needs of social-economic development [4]. To optimize the training program and curriculum system, the ability requirements of students in accreditation standards are decomposed into the teaching links of curriculum, operation, experiment, test, practice and design, and the mapping relationship between each teaching link and certification standard ability requirements is required to determine the goal of teaching.

\section{Production Integration, Grasping the New Requirements}

Fusion between production can promote the service sector, so as to improve professional academic and technical level, at the same time, in the process of production integration, colleges can further understand the demand of the industry, industry and facilitate the targeted training for personnel. Visibly, production integration is a good way to cultivate engineering and technical personnel, is a good practice to improve professional characteristics, and engineering education accreditation advocated education mode.

Strengthen the participation of industry engineering education, and cultivate the professional characteristics in the fusion of production and study. Invite the industry competent departments and enterprises to participate in the development of the training program and curriculum system, and cooperate with the enterprise to build the practice teaching system. There is a plan to invite engineering experts to participate in professional education from the freshmen. Employ the engineering and technical personnel of the enterprise to the school to teach, bring the problems and experience of the enterprise into the classroom. Take the students to the enterprise for on-site teaching; let students feel the enterprise production and management. Under the guidance of the enterprise tutor, students according to the training plan to the corresponding enterprise internship. Encourage students to graduate design, let students participate in enterprise project research. Pay attention to the cultivation of teachers' engineering practice ability, encourage engineering teachers to practice, part-time, part-time training and post work. Actively create conditions to strengthen and enterprises to apply for vertical scientific research projects, encourage engineering teachers to undertake the horizontal scientific research projects proposed by enterprises, and constantly improve the level of teachers' scientific research.

\section{To Explore the Diversity of Personnel Training, the Reform of Engineering Talent "Supply Side"}

The purpose of engineering education accreditation is not to provide a unique mode for the engineering specialty, and but by regulations, basic standards and promote the characteristic for engineering construction, according to the characteristics of engineering specialty are encouraged to diversified exploration, so as to realize the different characteristics of talent cultivation mode. Certification standards for different regions, different levels and different types of colleges and universities in the educational history, advantage, school-running orientation, including other differences, respect the school-running autonomy of universities and leave adequate reform space for the characteristic development of universities. Universities should be based on our practice, contrast analyze interpretation certification standards, to carry out the self-assessment, find out the gap of their shortage and characteristics, foster strengths and circumvent weaknesses, precision improvement, constantly improve the level of characteristic specialty construction.

The reform of the supply side of engineering talents is a systematic project, needs teaching facilities, teaching funds, teaching management and other conditions guarantee. To ensure the classroom resources and experimental equipment to meet the training needs of engineering talents; The characteristics and needs of various engineering professionals should be fully considered in the allocation of funds; Pay great attention to the construction of teachers, pay attention to the introduction of teachers with deep engineering background; Hold the engineering competition of various forms and various levels, and accredit the students to participate in scientific research, engineering design and other activities; Standardized teaching management and service, embodies moral sense and social responsibility in planning, construction, enrollment, finance, academic, personnel and other aspects.

\section{E. Take the Student as the Center, to Enhance the Student to Obtain}

In order to promote the development of colleges and universities around the students and training talents, all countries regard the students learning outcomes demand as the 
core content in engineering accreditation system. "Studentcentered" teaching model is the core concept of education and education of major update. School shall fully observe students needs, to help students succeed, support the development of students, make students become the target of the affairs of school bearing and the main participants, all the starting point and the ultimate aim of the education reform should fall on the student's actual income, improve the competitive ability of the students' employment, pay attention to cultivating students' consciousness and the ability of lifelong learning.

Extensive compulsory social and volunteer service activities, to strengthen college students' social sense of responsibility and sense of mission. Carrying out extracurricular production project and college students' innovative undertaking plan, make college students to have team spirit. Actively providing opportunities for students for international communication make the college students with global vision. Through a high level of talent training to enhance the students' feeling, laid a good foundation for the development of the students after graduation.

\section{F. Education Plus Internet Thinking, Continuously Strengthening Characteristics}

In the era of "Internet plus" should respect each student's personality characteristics for the engineering specialty, and study the difference of the students using the Internet technical support, let every student have a colorful life. With the help of online education to realize open special professional quality education resources sharing, promote the education fair. Actively explore the information technology and curriculum integration innovation, widely used in micro class, MOOC (Massive Open Online Courses) class, and flip class such as a new pattern of teaching. Three-dimensional structure network teaching resources system should be erected.

Through the Internet articles, reports, recruitment and advertising information such as the big data analysis, capture industry development characteristics, to grasp the industry development direction, and then to modify its training scheme, adapt to the needs of the industry, refining its own professional characteristics. Students use the Internet data, tracking study hot spot, looking for direction; meet the requirements for industry, and to lay a solid foundation for employment development. Teacher data via the Internet feel the industry pulse, reform the teaching content, the use of advanced teaching technology, and improve the teaching quality of education.

\section{CONCLUSION}

Engineering education accreditation and strengthen the education and engineering contact and cooperation, to promote the internationalization of engineering education process. Characteristic specialty is the advantages of running a university and the concentrated reflection of school-running characteristics, is the core competitiveness of school development. Characteristic specialty will more easily pass through the engineering education professional certification. Engineering education accreditation is conducive to the formation of the professional characteristics and strengthened.

In order to adapt to the national strategy of driver development by innovation, professional certification should regard the engineering specialty as a turning point, and the certification of attitude, goal oriented, uphold the concept of certification, regulate the behavior of certification, production integration and combining the modern information technology, the supply side of the reform of engineering and technical personnel, strengthen students' sense of gain, so as to realize the characteristic of professional development.

\section{ACKNOWLEDGMENT}

This paper is supported by the key education research project of Henan University of Science and Technology (Grant No. 2015YBZD-010).

\section{REFERENCES}

[1] D. Changan, "Engineering education professional certification pilot work on several issues of our country thinking", Journal of higher engineering education research, no. 2, pp. 27-32, 2011. (in Chinese)

[2] The higher school undergraduate teaching quality and teaching reform project leading group office, "On strengthening undergraduate "quality project' guidance for the construction of feature specialty", http://www.moe.edu.cn/publicfiles/business/htmlfiles/moe/A08_sjhj/201 109/xxgk_124352.html 2008. (in Chinese)

[3] Z. Jie, "Characteristic specialty construction in colleges and universities a long way to go, a questionnaire based on the country's 87 college leaders", Journal of national education administration institute, no.5, pp. 78-82, 2012. (in Chinese)

[4] The Chinese engineering education professional accreditation association, "about print and distribute 'engineering education professional accreditation standards (2015 edition)' notice “, http://ceeaa.heec.edu.cn/news.php?news_id=133. (in Chinese)

[5] W. Nan, "Higher education organization in the field of isomorphism phenomenon and its mechanism, based on the theory of organizational sociology of literature review and attribution of ", Journal of higher education in Jiangsu Province, no. 3 pp. 39-43, 2016. (in Chinese )

[6] The ministry of education of higher education teaching evaluation center "With the international standard authentication booster in engineering education quality improvement - 2016 engineering education professional certification training ended", http://www.pgzx.edu.cn/modules/peixundongtai_d.jsp?id=93525. （ in Chinese) 